\title{
Carbon Dioxide Capture and Utilization for Gas Engine
}

\author{
Takashi Ogawa \\ Power and Industrial Systems R\&D Center, Toshiba Corporation, Fuchu, Japan \\ Email: taka.ogawa@toshiba.co.jp
}

Received November 2, 2013; revised December 2, 2013; accepted December 9, 2013

Copyright (C) 2013 Takashi Ogawa. This is an open access article distributed under the Creative Commons Attribution License, which permits unrestricted use, distribution, and reproduction in any medium, provided the original work is properly cited. In accordance of the Creative Commons Attribution License all Copyrights (C) 2013 are reserved for SCIRP and the owner of the intellectual property Takashi Ogawa. All Copyright (C) 2013 are guarded by law and by SCIRP as a guardian.

\begin{abstract}
Sodium glycinate absorption and ethylene carbonate synthesis from a mixture gas of ethylene oxide and carbon dioxide are evaluated as carbon dioxide capture and utilization system for gas engine flue gas. The energy requirement for $\mathrm{CO}_{2}$ capture is estimated at $3.3 \mathrm{GJ} /$ tonne $\mathrm{CO}_{2}$. The ethylene carbonate synthesis utilizes more than $90 \%$ of the captured $\mathrm{CO}_{2}$ and supply $2.5 \mathrm{GJ} /$ tonne $\mathrm{CO}_{2}$ of thermal energy, which is $76 \%$ of the energy requirement for $\mathrm{CO}_{2}$ capture. The thermal integration of the sodium glycinate absorption and the ethylene carbonate synthesis reduces the energy requirement for $\mathrm{CO}_{2}$ capture from $3.3 \mathrm{GJ} /$ tonne $\mathrm{CO}_{2}$ to $0.8 \mathrm{GJ} /$ tonne $\mathrm{CO}_{2}$. The energy requirement for the $\mathrm{CO}_{2}$ capture is supplied using the steam saturated at $0.78 \mathrm{MPa}$ from the gas engine without its electric power reduction.
\end{abstract}

Keywords: Carbon Dioxide Capture; Carbon Dioxide Utilization; Carbonate Formation; Gas Engine

\section{Introduction}

Over the past decade, the global warming resulting from anthropogenic carbon dioxide $\left(\mathrm{CO}_{2}\right)$ has become one of the most important environmental matters. A quarter of the $\mathrm{CO}_{2}$ emissions all over the world are exhausted from thermal plants. Post-combustion carbon dioxide capture is the technique that can be rapidly and safely employed for substantially reducing carbon dioxide emissions from existing and near future power plants [1]. The captured $\mathrm{CO}_{2}$ is compressed, transported, and stored in depleted oil and gas fields [2].

A gas engine has been used as a combined heat and power system. The flow rate of carbon dioxide in its flue gas is short to carbon capture and storage, especially for transporting and storing captured carbon dioxide. Therefore, plant fertilization at a greenhouse is used to utilize the captured $\mathrm{CO}_{2}$ from a gas engine [3]. However, the plant fertilization needs the large area and is not capable of supplying the heat of $\mathrm{CO}_{2}$ capture.

North reported ethylene carbonate synthesis from dilute $\mathrm{CO}_{2}$ and dilute ethylene oxide uses a gas-phase continuous flow reactor near conditions of ambient temperature and pressure. The synthesis is highly exothermic reaction and the rate of the reaction is high [4]. The ethylene carbonate synthesis from pure $\mathrm{CO}_{2}$ was not estimated using a gas-phase reactor. Weiland reported so- dium glycinate can remove $\mathrm{CO}_{2}$ from the flue gas of a coal-fired thermal plant [5]. It was not estimated in the case of the flue gas of a gas engine, whose $\mathrm{CO}_{2}$ concentration is much lower than that of a coal-fired thermal plant.

In this paper, we evaluated sodium glycinate absorption as $\mathrm{CO}_{2}$ capture and ethylene carbonate synthesis as the captured $\mathrm{CO}_{2}$ utilization and heat recovery for a gas engine.

\section{Carbon Dioxide Capture and Utilizatio System}

\subsection{Gas Engine}

Table 1 shows the specifications of the $\mathrm{KV}-18-\mathrm{V}$ gas engine made by Kawasaki Heavy Industries, Ltd [6]. The $\mathrm{KV}-18-\mathrm{V}$ gas engine has achieved a thermal efficiency of $49 \%$ on the basis of lower heating value and provide 7.8 MW of electric power, 2.3 MW of thermal power as steam saturated at $0.78 \mathrm{MPa}$, and $3.3 \mathrm{MW}$ of thermal power as hot water at $88^{\circ} \mathrm{C}$. The fuel is city gas $13 \mathrm{~A}$ [7] and the flow rate is $1412 \mathrm{Nm}^{3} / \mathrm{h}$. The flue gas composition and flow rate are estimated under the assumptions; 1 ) air consists of oxygen (20.95\%) and nitrogen (79.05\%) [8], 2) the air-to-fuel ratio is 2.2 [9]. Those result in that the flue gas composition is a mixture of $\mathrm{CO}_{2}(4.72 \%)$, $\mathrm{H}_{2} \mathrm{O}(8.77 \%), \mathrm{O}_{2}(10.92 \%)$, and $\mathrm{N}_{2}(75.59 \%)$ and the 
Table 1. Specifications of KV-18-V gas engine.

\begin{tabular}{cc}
\hline Electric power & $7800 \mathrm{~kW}$ \\
\hline Electric efficiency $^{\mathrm{a}}$ & $49.0 \%$ \\
Steam output $^{\mathrm{a}}$ & $14.4 \%$ \\
Hot water output $^{\mathrm{b}}$ & $20.6 \%$ \\
\hline Fuel & City gas $13 \mathrm{~A}$ \\
Flow rate & $1412 \mathrm{Nm}^{3} / \mathrm{h}$ \\
Composition & $\mathrm{CH}_{4}(89.60 \%), \mathrm{C}_{2} \mathrm{H}_{6}(5.62 \%)$, \\
Lower heating value & $\mathrm{C}_{3} \mathrm{H}_{8}(3.43 \%), \mathrm{C}_{4} \mathrm{H}_{12}(1.36 \%)$ \\
\hline
\end{tabular}

${ }^{\mathrm{a}} 0.78 \mathrm{MPa}$ saturation, Inlet temperature: $60^{\circ} \mathrm{C}$; ${ }^{\mathrm{b}}$ Inlet/outlet temperature: $83^{\circ} \mathrm{C} / 88^{\circ} \mathrm{C}$.

flow rate of the flue gas is $34,857 \mathrm{Nm}^{3} / \mathrm{h}$.

\subsection{Carbon Dioxide Capture System}

Figure 1 shows a carbon dioxide capture system. The system consists of an absorber, a rich-lean heat exchanger, a stripper, and a lean cooler. The flue gas enters the bottom of the absorber and an absorbing solvent enters the top of the absorber. The absorbing solvent selectively absorbs $\mathrm{CO}_{2}$ from the flue gas. The $\mathrm{CO}_{2}$ rich solvent from the bottom of the absorber passes through the rich-lean heat exchanger to preheat. The preheated $\mathrm{CO}_{2}$ rich solvent enters at the top of the stripper. Then it is heated by the steam from a reboiler and desorbs $\mathrm{CO}_{2}$. The desorbed $\mathrm{CO}_{2}$ is separated from the steam at the top of the stripper. The $\mathrm{CO}_{2}$ lean solvent from the bottom of the stripper is cooled using the rich-lean heat exchanger and the lean cooler. The cold $\mathrm{CO}_{2}$ lean solvent is recirculated to the top of the absorber.

Table 2 shows the design conditions of the $\mathrm{CO}_{2}$ capture system. The absorbing solvent is $45 \mathrm{wt} \%$ Sodium Glycinate. The absorber inlet temperatures of the flue gas and the cold lean solvent are $40^{\circ} \mathrm{C}$. A temperature of approach of $4^{\circ} \mathrm{C}$ is chosen for the rich-lean heat exchanger. The absorber and stripper have $18 \mathrm{~m}$ and $9 \mathrm{~m}$ height beds using Sulzer Mellapak M250.X structured packing, respectively. They are sized for $50 \%$ of flood. The operation pressure of the stripper is $200 \mathrm{kPa}$. The carbon dioxide capture system is simulated using the ProTreat ${ }^{\circledR}$ software (Optimized Gas Treating, Inc.).

\subsection{Ethylene Carbonate Synthesis System}

Figure 2 shows an ethylene carbonate synthesis system. The ethylene carbonate synthesis system consists of a heat exchanger and a Gibbs reactor, for which the reaction equilibrium is calculated by minimizing the Gibbs free energy at specified temperature and pressure.

An equimolar mixture gas of the captured $\mathrm{CO}_{2}$ and ethylene oxide (EtO) enters the heat exchanger at $40^{\circ} \mathrm{C}$ and is preheated. The preheated mixture enters the Gibbs reactor and forms ethylene carbonate $\left(\mathrm{EtCO}_{3}\right)$ from $\mathrm{CO}_{2}$

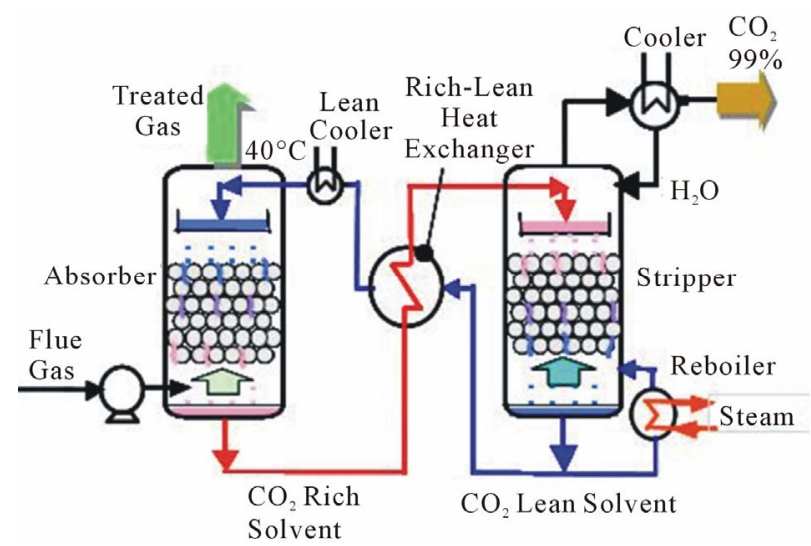

Figure 1. Carbon dioxide capture system.

Table 2. Design conditions of $\mathrm{CO}_{2}$ capture system.

\begin{tabular}{|c|c|c|}
\hline Solvent & Sodium Glycinate & 45 wt. $\%$ \\
\hline \multirow{5}{*}{ Absorber } & Packing & $\begin{array}{c}\text { Sulzer Mellapak } \\
\text { M250.X }\end{array}$ \\
\hline & Packing Height & $18 \mathrm{~m}$ \\
\hline & Flood & $50 \%$ \\
\hline & Solvent Inlet Temperature & $40^{\circ} \mathrm{C}$ \\
\hline & Flue gas Inlet Temperature & $40^{\circ} \mathrm{C}$ \\
\hline \multirow{6}{*}{ Stripper } & Packing & $\begin{array}{c}\text { Sulzer Mellapak } \\
\text { M250.X }\end{array}$ \\
\hline & Packing Height & $18 \mathrm{~m}$ \\
\hline & Flood & $50 \%$ \\
\hline & Cooler Exit Temperature & $40^{\circ} \mathrm{C}$ \\
\hline & Cooler Exit Pressure & $200 \mathrm{kPa}$ \\
\hline & Reboiler Operating Pressure & $200 \mathrm{kPa}$ \\
\hline $\begin{array}{l}\text { Rich-Lean Heat } \\
\text { Exchanger }\end{array}$ & Approach Temperature & $4^{\circ} \mathrm{C}$ \\
\hline
\end{tabular}

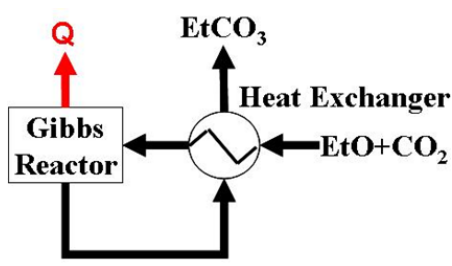

Figure 2. Ethylene carbonate synthesis system.

and ethylene oxide exothermically. The synthesized ethylene carbonate is cooled in the heat exchanger. A temperature of approach of $10^{\circ} \mathrm{C}$ is chosen for the heat exchanger. The ethylene carbonate synthesis system is simulated using the VMGSim ${ }^{\circledR}$ software (Virtual Material Group Inc.) with Advanced Peng-Robinson property package. The temperature of ethylene oxide at the heat exchanger exit is higher than $40^{\circ} \mathrm{C}$, which is higher than the melting point of ethylene carbonate $\left(34^{\circ} \mathrm{C}\right.$ $\left.37^{\circ} \mathrm{C}\right)$. 


\section{Results and Discussion}

\subsection{Carbon Dioxide Capture}

Figure 3 shows a plot of $\mathrm{CO}_{2}$ recovery ratio as functions of the flow rate of the $\mathrm{CO}_{2}$ lean solvent and the reboiler duty. The $\mathrm{CO}_{2}$ recovery ratios at the different reboiler duty have peaks at the flow rate of the $\mathrm{CO}_{2}$ lean solvent of 60 tonne/h $(\mathrm{t} / \mathrm{h})$.

Figure 4 shows a plot of the energy requirement for $\mathrm{CO}_{2}$ capture $\left(\mathrm{CO}_{2}\right.$ recovery energy) as a function of the $\mathrm{CO}_{2}$ recovery ratio at $60 \mathrm{t} / \mathrm{h}$ of the flow rate of the $\mathrm{CO}_{2}$ lean solvent. The $\mathrm{CO}_{2}$ recovery energy increases linearly with the $\mathrm{CO}_{2}$ recovery ratio.

We aimed for $0.098 \mathrm{kgCO}_{2} / \mathrm{kWh}$ of carbon dioxide emission factor, which is equal to that of a coal-fired thermal plant with $90 \%$ of $\mathrm{CO}_{2}$ recovery on the basis of gross power [10]. This results in $76.5 \%$ of $\mathrm{CO}_{2}$ recovery from the flue gas of the $\mathrm{KV}-18 \mathrm{~V}$ gas engine and indicates $3.3 \mathrm{GJ} /$ tonne $\mathrm{CO}_{2}\left(\mathrm{GJ} / \mathrm{tCO}_{2}\right)$ of the $\mathrm{CO}_{2}$ recovery energy. The KV-18V gas engine can supply $3.2 \mathrm{t} / \mathrm{h}$ of the steam saturated at $0.78 \mathrm{MPa}$, whose energy is equal to the $3.3 \mathrm{GJ} / \mathrm{tCO}$ of the $\mathrm{CO}_{2}$ recovery energy.

\subsection{Ethylene Carbonate Synthesis}

Figure 5 shows a plot of degrees of $\mathrm{CO}_{2}$ conversion by ethylene carbonate synthesis against reaction temperatures at $101.3 \mathrm{kPa}$. The degree of conversion decreases stepwise at temperature of $133^{\circ} \mathrm{C}$ and above. The vapor pressures of ethylene carbonate are lower than the partial pressures of that at the equilibrium state of the reaction which produces ethylene carbonate at temperature of $133^{\circ} \mathrm{C}$ and below. It results in the liquefaction of ethylene carbonate and more than $90 \%$ of the conversion.

Figure 6 shows a plot of the generated heat per the captured $\mathrm{CO}_{2}$ against the reaction temperatures at 101.3 $\mathrm{kPa}$. The reaction heat of the synthesis is almost the same among the reaction temperatures and the total amount of heat generated by the synthesis increases with the degree of conversion. That results in the similar trend between the degree of conversion and the generated heat per the captured $\mathrm{CO}_{2}$. The synthesis generates $2.5 \mathrm{GJ} / \mathrm{tCO}_{2}$ of thermal energy at temperature of $133^{\circ} \mathrm{C}$ and below.

Figure 7 shows a plot of maximum reaction temperatures of nonequilibrium state as a function of reaction pressures. The degree of conversion at the state of nonequilibrium is more than $90 \%$. The maximum reaction temperature is higher than $120^{\circ} \mathrm{C}$ of the operation temperature of the reboiler.

The ethylene carbonate synthesis can supply $76 \%$ of the $\mathrm{CO}_{2}$ recovery energy and utilize more than $90 \%$ of the captured $\mathrm{CO}_{2}$. The thermal integration of the sodium glycinate absorption carbon capture and the ethylene carbonate synthesis systems reduces the $\mathrm{CO}_{2}$ recovery energy from $3.3 \mathrm{GJ} / \mathrm{tCO}_{2}$ to $0.8 \mathrm{GJ} / \mathrm{tCO}_{2}$.

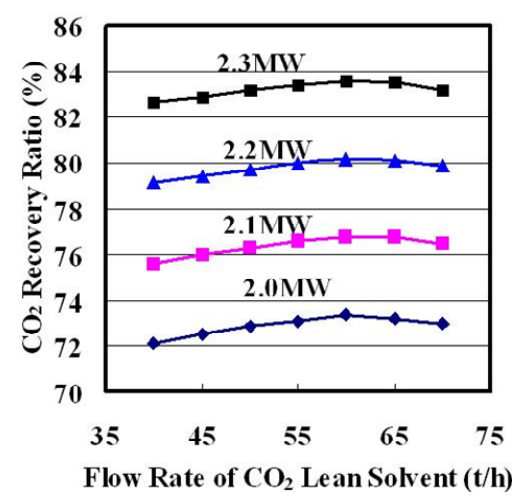

Figure 3. $\mathrm{CO}_{2}$ recovery ratio as functions of flow rate of $\mathrm{CO}_{2}$ lean solvent and reboiler duty.

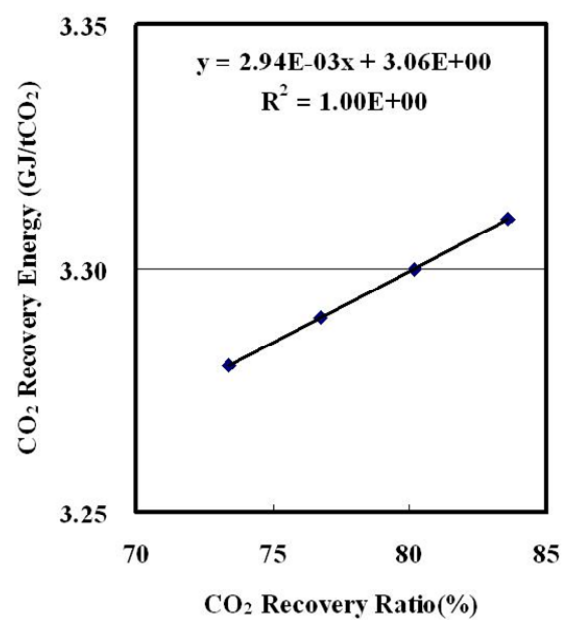

Figure 4. $\mathrm{CO}_{2}$ recovery energy a function of $\mathrm{CO}_{2}$ recovery ratio.

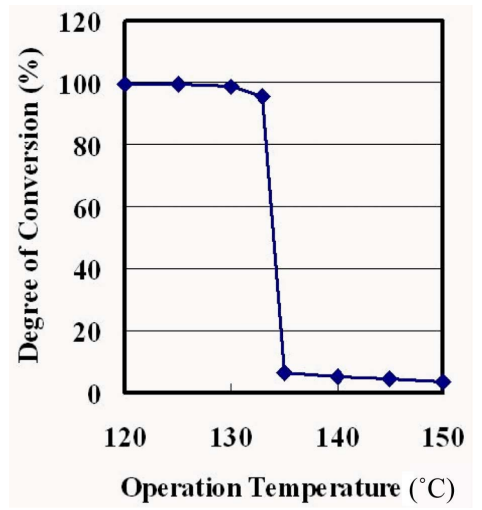

Figure 5. Degree of conversion as a function of operation temperature at $101.3 \mathrm{kPa}$.

\section{Conclusion}

The ethylene carbonate synthesis using the carbon dioxide recovered from the gas engine flue gas can supply $76 \%$ of the energy requirement for $\mathrm{CO}_{2}$ capture and utilize more than $90 \%$ of the captured $\mathrm{CO}_{2}$. The thermal integration of the sodium glycinate absorption and the 


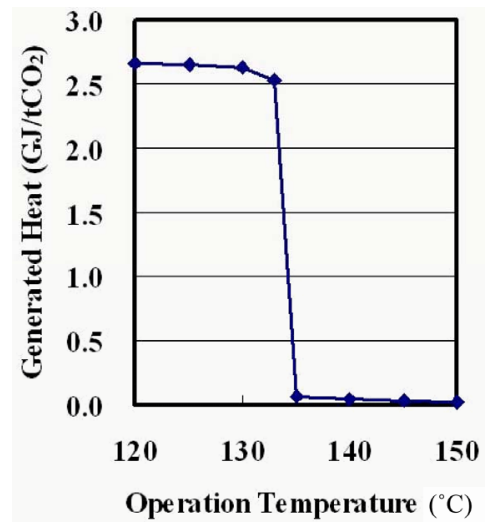

Figure 6. Generated heat as a function of operation temperature at $101.3 \mathrm{kPa}$.

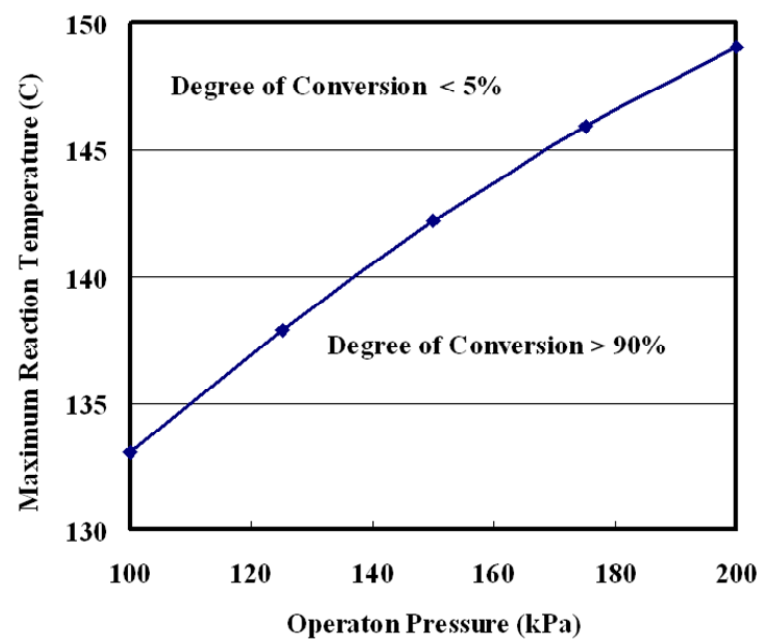

Figure 7. Maximum reaction temperature as a function of operation pressure.

ethylene carbonate synthesis reduces the energy requirement for $\mathrm{CO}_{2}$ capture from $3.3 \mathrm{GJ} / \mathrm{tCO}$ to $0.8 \mathrm{GJ} / \mathrm{tCO}_{2}$. The energy requirement for the $\mathrm{CO}_{2}$ capture can be supplied by $0.78 \mathrm{MPa}$ saturation steam from the gas engine without its electric power reduction.

\section{REFERENCES}

[1] T. Ogawa, Y. Ohashi, S. Yamanaka and K. Miyaike, "Development of Carbon Dioxide Removal System from the Flue Gas of Coal Fired Power Plant,” Energy Procedia, Vol. 1, No. 1, 2009, pp. 721-724. http://dx.doi.org/10.1016/j.egypro.2009.01.095

[2] International Energy Agency, "Carbon Capture and Storage.” http://www.iea.org/topics/ccs/

[3] T. Hallerman, "GE Pushes Dual Plant Fertilization- $\mathrm{CO}_{2}$ Utilization Technology,” GHG News, 2012. http://ghgnews.com/index.cfm/ge-pushes-dual-plant-fertil ization-co2-utilization-technology/

[4] M. North, P. Villuendas and C. Young, “A Gas-Phase Reactor for Ethylene Carbonate Synthesis from Waste Carbon Dioxide," Chemistry A European Journal, Vol. 15, No. 43, 2009, pp. 11454-11457. http://dx.doi.org/10.1002/chem.200902436

[5] R. H. Weiland and N. A. Hatcher, "Post-Combustion $\mathrm{CO}_{2}$ Capture with Amino-Acid Salts," SOGAT 2011-7 $7^{\text {th }}$ International Sour Oil \& Gas Advanced Technology, Abu Dhabi, 2011.

http://www.ogtrt.com/files/publications/Manuscript_CO2 _Capture_with_Amino_Acid_Salts.pdf

[6] Nihhon Kougyou Syuppan Kuriin Enerugii Hensyuubu, “Tennen Gasu Kohzyenereeshon Kiki Deeta,” Nihhon Kougyou Syuppan, 2012.

[7] Tokyo Gas, "City Gas 13A-Heating Value, Composition,” (in Japanese). http://home.tokyo-gas.co.jp/userguide/netsuryou.html

[8] "Sea-Level Composition of Air." http://www.physlink.com/reference/aircomposition.cfm

[9] Wartsila, "Wartsila 50SG Engine Technology." http://www.wartsila.com/file/Wartsila/1278515598410a1 267106724867-50SG-Engine-Technology-2012.pdf

[10] H. Hondo, Y. Uchiyama and Y. Morizumi, "Evaluation of Power Generation Technologies based on Life Cycle $\mathrm{CO}_{2}$ Emissions-Re-Estimation Using the Latest Data and Effects of the Difference of Conditions)," CRIEPI Research Report, 2000.

http://criepi.denken.or.jp/jp/kenkikaku/report/detail/Y990 09. html 